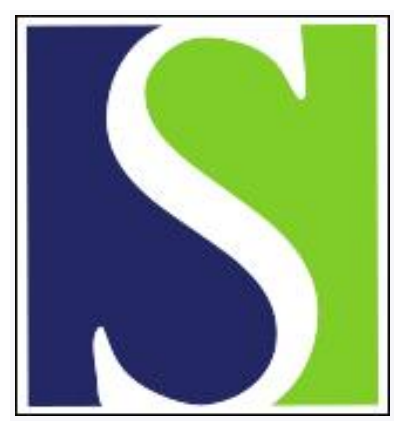

Scand J Work Environ Health 1994;20(3):166-179

https://doi.org/10.5271/sjweh.1412

Issue date: 01 Jun 1994

Potential parental exposure to pesticides and limb reduction defects.

by Lin S, Marshall EG, Davidson GK

Affiliation: Bureau of Environmental and Occupational Epidemiology, New York State Department of Health, Albany.

This article in PubMed: www.ncbi.nlm.nih.gov/pubmed/7973488

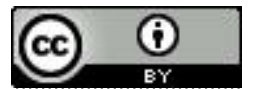




\title{
Potential parental exposure to pesticides and limb reduction defects
}

\author{
by Shao Lin, PhD, ${ }^{1}$ Elizabeth G Marshall, PhD, ${ }^{1}$ Georgia K Davidson, MA ${ }^{1,2}$
}

LIN S, MARSHALL EG, DAVIDSON GK. Potential parental exposure to pesticides and limb reduction defects. Scand J Work Environ Health 1994;20:166-179.

\begin{abstract}
OBJEctives - The goal of the study was to examine the effects of the potential pesticide exposure of parents on the risk of limb reduction defects in their offspring.

Methons - A case-referent study was conducted utilizing New York State Congenital Malformation Register data. Persons with limb reduction defects and referents were compared in terms of parental occupations and residence counties. Parental occupations and industries reported on birth certificates were qualitatively rated by industrial hygienists to estimate potential pesticide (list four groups) exposures. Residential exposures were estimated from agricultural census data according to county of residence.

RESULTs - Neither parental exposure to pesticides [odds ratio (OR) $0.9,95 \%$ confidence interval $(95 \%$ CI) $0.6-1.4]$ nor farming occupation (OR $1.1,95 \%$ CI $0.5-2.7$ ) had an effect on the risk of total limb reduction defects. Those persons with limb reduction defects who had additional defects showed weak but consistent elevated risks in relation to parental occupational pesticide exposure. However, isolated cases of limb reduction defects were negatively related to these exposures. Residence in a farming or high pesticide use county was not associated with any type of limb reduction defect.

Conclusions - Cases of limb reduction defect with additional malformations appear to be associated with parental occupational pesticide exposure. Improving exposure classifications and subdividing the limb reduction defects by types in the analyses are suggested for future research.
\end{abstract}

Key terms: farming, limb reduction malformation, occupational pesticide exposure, residential pesticide exposure.

The incidence of limb reduction defects varies from 0.40 to 0.62 per 1000 live births (1). Although some of the variation in the rate of limb reduction defects may be attributable to differences in the study population or methods of ascertainment, environmental or occupational exposures may contribute to some of the variation in the rate of occurrence. Limb development is susceptible to teratogenic agents, as evidenced by the thalidomide disaster. Compared with many other types of malformations, limb reduction defects are thought to be well-reported. Therefore, the health effects of possible environmental teratogens can be assessed from an evaluation of the variation in the incidence of limb reduction defects.

Pesticides have been found to produce cancers or congenital deformities in animals (2-4) and human fetuses (5). The exact mechanism by which pesticides might produce birth defects is not clearly understood and differs by chemical. For example, captan was

Bureau of Environmental and Occupational Epidemiology, New York State Department of Health, Albany, New York, the United States.

2 Current affiliation: Bureau of Maternity Services and Family Planning, New York City Department of Health, New York, New York, the United States.

Reprint requests to: Dr S Lin, New York State Department of Health, Two University Place, Room 135, Albany, NY 12203 , USA. reported to produce chromosome aberrations in rats (3). Herbicides such as chlorophenoxy compounds have also been found to decrease fertility and neonatal survival significantly in first-generation rats (4). Malathion has been shown to alter the electrical activity of human brain and induce abnormalities in the central nervous system and skeleton of fetuses (5).

Some human studies have demonstrated a positive relationship between parental agricultural activity and malformations other than limb reduction defects and stillbirths (6-8).

Several studies have examined relationships between parental pesticide exposures and limb reduction defects in their infants. Conclusive evidence of an association is, however, uncertain because of several problems, including small sample size, incomplete case ascertainment, inaccurate case diagnosis, and biased recall of exposure. Two ecologic studies found a correlation between pesticide exposure and the prevalence of limb deformity $(9,10)$. In one, from India, the limb reduction defects were only a subset of the possible limb deformities, and the study had inadequate statistical power (9). Schwartz et al (10), in a cross-sectional study, illustrated that agricultural workers had a relative risk of 2.3 for having limb reduction defects in their offspring compared with people in other occupations. However, this finding was based on a very small number of cases of limb reduction defects $(\mathrm{N}=8)$. 
Several analytic studies have also found positive associations between pesticide exposures and limb reduction defects $(11-13)$. In a second study using birth certificates for case ascertainment, Schwartz \& LoGerfo (11) found no increased risk of parenting a child with a limb reduction defect among parents involved in agricultural work. However, they found a significant excess of limb reduction defects among children born to mothers residing in a county of high agricultural productivity [odds ratio (OR) 1.7, 95\% confidence interval $(95 \% \mathrm{CI}) 1.1-2.7]$ or residing in a county with high pesticide use (OR $1.9,95 \%$ CI 1.2-3.1) as compared with the effects of minimal exposure. Munger et al (12) showed an increased risk (OR 6.9, 95\% CI 4.2-11.0) for limb reduction defects in association with residences exposed to pesticide-contaminated water supplies in Iowa. Kricker et al (13) reported a significant association between limb reduction defects and self-reported pesticide use during pregnancy, including garden and workplace exposure, household infestation treatment, and chemical sprays used next door. However, women were asked to recall exposure from over four years previously and the interviewers were not blind to birth outcome. On the other hand, Roan et al (14) compared families engaged in agricultural aviation and cooperating sibling families, and there were no differences in spontaneous abortions or birth defects between the two groups. Two other studies have also failed to confirm a positive association between pesticide exposure and limb reduction defects $(15,16)$.

The objective of the current case-referent study was to compare the frequencies of parental occupational exposure to pesticides, farming in general, and residence in an agricultural setting between cases of limb reduction defects and their referents. In addition, the effects of parental demographics on the risk of limb reduction defects were also assessed.

\section{Subjects and methods}

\section{Identification of subjects}

Cases of limb reduction defects. All of the cases included in this study were ascertained from the New York State Congenital Malformations Register. This register monitors the occurrence of all congenital anomalies and persistent metabolic defects among live births in New York State (17). Health care providers in New York State (primarily hospitals) are required by law to report all congenital malformations among children under two years of age by using a specially designed reporting card. Reported birth defects are coded by trained staff according to the ninth revision of the International Classification of Diseases (ICD-9) of the World Health Organization (18). Periodic audits of hospital birth and treatment records encourage, but do not guarantee, complete reporting (17). Since limb reduction defects are relatively obvious malformations at birth, it is ex- pected that the majority of limb reduction defects is reported.

The case selection procedure has been described previously (1). In summary, any live birth with an ICD code of $755.2,755.3$ or 755.4 from 1983 to 1987 was defined as a potential case of limb reduction defect. After the exclusion of cases born in New York City, cases with generalized growth problems or chromosome abnormalities, dwarfs, multiple births, and inadequate clinical descriptions, there were 277 limb reduction defects in the final case group.

The persons with a limb reduction defect who also had other malformations reported to the Congenital Malformations Register were defined as cases having associated limb reduction defects. The associated defects included are within the range of the ICD-9 from 740.0 to 759.9 . Among them, we excluded some diagnoses because they were either minor or inconsistently reported for infants [eg, congenital subluxation of the hip, spina bifida occulta, congenital hydrocephalus or ventricular septal defects in very low birthweight infants (1)]. Syndactyly or polydactyly in the same limb as the limb reduction defect was not considered an additional malformation. The cases of limb reduction defects without any other malformations were defined as isolated limb reduction defects.

Referents. Two groups of referents, both of which were upstate liveborn infants without any limb reduction defects, were used in this study. Each group of referents was frequency matched (1 to 1 ) by birth year to the case group. The first group of referents was chosen from the Congenital Malformations Register between 1983 and 1987. Since most of the other malformations were expected to be reported in a fashion similar to limb reduction defects, potential biases introduced from inconsistencies in register reporting could be examined with the use of the malformed reference group. A computer program was developed to pick infants with major malformations at random. A list of malformation diagnoses was developed by the Birth Defect Monitoring Program (BDMP) of the Center for Disease Control (19) to monitor changes in the occurrence of major defects. The major malformations include such defects as anencephaly, encephalocele, or choanal atresia/stenosis. These conditions are believed to be easily diagnosed during the newborn period. Limb reduction defects are included on this list, although obviously excluded from the reference group in this study. Thus we expected the reporting pattern of the referents with other malformations to be similar to that of limb reduction defects.

Normal referents consisted of a systematic random sample of all upstate live births occurring during the study period and chosen from birth certificates. Any infant reported to the Congenital Malformations Register with any major malformation was excluded 
from the normal reference group. Because other cases included in the reference group with other malformations could potentially be related to pesticide exposure, this normal reference group would be expected to represent the general newborn population born without malformations.

Similar to the cases, those referents born in New York City or to New York City or out-of-state residents were excluded from both reference groups. In addition we deleted persons with chromosome defects or dwarfism and multiple births from the referents with other malformations.

\section{Data collection and quality}

The data for this study were obtained from the following three sources: (i) the Congenital Malformation Register, (ii) New York State birth certificates (20), and (iii) 1983-1987 agricultural census data for New York State (21).

Because register reports are not detailed enough to characterize limb reduction defects sufficiently, medical records were requested and obtained from the hospitals of birth or treatment for all but three eligible cases. Each medical record was abstracted on a detailed abstract form that summarized the clinical descriptions [ie, location and extent of the reduction(s)], accompanying defects, X-ray reports, and autopsy reports, if applicable. All of the charts were independently reviewed by two persons, and any discrepancies or ambiguities were resolved by consultation with medical staff of the Register.

Parental occupational information for the cases and referents was abstracted from paper copies of the birth certificates since this information is not routinely coded or computerized. The abstracted information included usual occupation of father, most recent occupation of mother, parental business and industry, and name and location of firm or company. For mothers who had never been employed, homemaker or student was noted. Subsequently, these data were coded by a trained nosologist using the classification system employed by the United States Census Bureau for coding occupation and industry (22). All codings were checked by two persons and double entered to reduce errors.

Demographic variables, including race, gender, maternal age and education level, gestational age, birthweight, and parity, were obtained from computerized birth records. The agreement of this information for New York State births (excluding New York City), with hospital records, is high (23). In addition, most of these variables were verified by data from the Congenital Malformations Register and medical records. About $88 \%$ of the children born in upstate New York are white, and the majority $(75-80 \%)$ of all nonwhite children born in upstate New York are black (20). Therefore, for the analysis we grouped all nonwhites together. Data on perinatal complications were available from both birth certificates and medical charts. Complications included eclampsia, preeclampsia, hypertensive disease, abnormal uterine bleeding in the first, second or third trimester, and genital herpes.

\section{Assessment and definition of exposure}

We chose three complementary measures to estimate the degree of gestational exposure to agricultural pesticides. These measures included parental involvement in a potentially pesticide-exposed occupation, maternal residence in a county with high per capita acreage of farm lands, and maternal residence in a county with high pesticide use per acre of farmland. Thus the outcome status, parental occupation, and demographics were based on individual information, while the indicators of residence in an agricultural county or high pesticide-use county were ecological, surrogate measures.

In order to determine which occupations have potential pesticide exposure, two experienced industrial hygienists reviewed all industry-occupation combinations and grouped them into the following categories: no or minimal pesticide exposure, potential exposure to disinfectants, herbicides, fungicides or insecticides, and unknown. The exposure groups were assigned without any knowledge of birth outcome. When the industrial hygienists disagreed with the assigned rating, a third industrial hygienist made a final decision. Therefore, any industry-occupation combination which satisfied the industrial hygienists' exposure criteria was considered pesticide-exposed. Housewives, students, or unemployed people were defined as having low or no pesticide exposure. Some pesticides, such as chlordecone, which has been reported to induce abnormal sperm morphology and histological alterations of spermatogenesis (24), and ethylene dibromide, which has reduced semen volume and motility in exposed men (25), may operate through male-mediated effects on pregnancy outcomes. Therefore, the potential effects of paternal exposures during the preconceptional period were examined. A category termed parental pesticide exposure (either paternal or maternal exposure to any pesticide in any occupation) was also used in this study. On the other hand, nonexposure was assigned if neither parent was exposed to any class of pesticide. Appendices 1 and 2 show the combination of different industry and occupational codes in the current study and their pesticide exposure ratings. Farming occupations accounted for only a small percentage of the potentially exposed occupations.

Maternal county of residence was linked with the 1983-1987 New York State Census of Agriculture (21) to create two ecological indicators. The first measure was based on the total acres of land in farms by county for 1987 , expressed as a per-capita measure. The second measure was the total acres of farmland on which the following four types of chemicals were used in 1987: insecticides, herbi- 
cides, nematocides, and fungicides. In order to standardize for county size, the pesticide use was expressed as acres of treated farmland. The rate of pesticide use was divided into low, medium, and high categories based on 33, 66 and $>66 \%$ of the distribution of pesticide use per acre over all counties. For example, the amount of farmland and the population in Albany County are 67754 acres (167 $352 \mathrm{ha}$ ) and 282500 people, respectively. The total farmland per capita in Albany is 0.24 acres (ie, $67754 / 282500)(0.59 \mathrm{ha})$, which is classified as "medium." There are 2947 acres (7279 ha) on which insecticide are used. The rate of insecticide use was 4\% (2947/67 754) in Albany County, classified as "low." For the multiple pesticide-use score for each county, 0 refers to low exposure to all four types of pesticides and 1, 2,3, or 4 indicates high exposure to any one, two, three, or four types of pesticides, respectively.

\section{Statistical analysis}

All of the analyses were based on the characteristics of the 277 cases remaining after exclusions. Chisquare tests were performed first for a comparison of overall frequencies between the cases of limb reduction defects and the two reference groups for demographic characteristics, parental occupational exposure to pesticides, maternal residence in an agricultural setting or high pesticide-use county. Odds ratios (OR) (including the 95\% CI) of all limb reduction defect case groups (total limb reduction defects, isolated limb reduction defects, or associated limb reduction defects) were estimated from a comparison of the frequency of exposure among the cases with that of the normal referents. In terms of parental occupational exposure to pesticides, the proportion of either parent exposed was compared with a reference group of neither parent exposed. Parental occupations designated as military, uncodable, or missing were considered missing, and those designated as homemaker, student, or no occupation were defined as unexposed. Analyses were repeated with and without homemakers, students, or no occupation considered unexposed to verify this assumption. $\mathrm{Pa}-$ rental farming designation was based on the standard classification index of occupation and industry of the United States Census Bureau (22). On the basis of five quintiles $(\mathrm{I}-\mathrm{V})$ of population density in New York State, a county was defined as a rural area when the quintile was I to II, suburban when the quintile was III to IV, and urban when the quintile was V. To exclude the effects of other potential risk factors of limb reduction defects present in suburban or urban areas $(57 \%)$, only residents of rural areas were used for the county land and pesticide analyses. The effect of county farmland per acre and county pesticide use per acre of farmland was evaluated by comparing the high exposure category with the low and medium groups.
An unconditional multiple logistic regression analysis was used to control for all potential confounding factors simultaneously when the association of primary interest was examined. In this model, a woman living in a county with high exposure to any of the four classes of pesticides at the time of delivery was defined as having high county pesticide exposure. The initial variables included were parental farming status and paternal and maternal potential occupational pesticide exposure. No significantly collinear problems were found among these variables. Potentially confounding variables related to limb reduction defects in the crude analyses, such as residence in a rural or an urban county, residence in a county with high pesticide use, infant gender, and maternal complications during pregnancy, were originally put into the model. This analysis included the subjects in all of the counties. Except for known risk factors, variables that did not alter the estimate of the exposure odds ratio were removed. The outcome variable was status (limb reduction defects or normal referents). In order to assess how different patterns of limb reduction defects affect these associations, we examined the total limb reduction defect cases, isolated limb reduction defects, and associated limb reduction defects (limb reduction defect cases with at least one additional malformation not directly related to the limb reduction defect) separately.

\section{Results}

Table 1 presents the demographic characteristics of the cases and referents. Infant gender, race, maternal age, maternal education levels, the trimester of first prenatal care, previous spontaneous fetal deaths, and season of first trimester were similar in all three study groups. However, there was a higher percentage of urban residents and a lower percentage of suburban residents among mothers of children with limb reduction defects and with other malformations compared with mothers of normal referents. In addition, pregnancy complications, preterm delivery $(<37$ weeks), and low birthweight $(<2500 \mathrm{~g})$ were highly related to both limb reduction defects and other malformations.

The association between potential parental exposure in pesticide-related occupations and the occurrence of limb reduction defects was examined by comparing the frequency of exposure among all of the limb reduction defect cases with that among the normal referents (table 2). In the current study, parents involved in farming were rated as having multiple or high-frequency exposures to pesticides. Employment as construction laborers or other laborers, nurses or health aides, clinical laboratory technicians, or in food preparation or service occupations such as cooks and waiters was the most frequent type of employment potentially exposed to pesticides in this study. Since the exposure frequency among the ref- 
Table 1. Distribution of selected demographics among the cases of limb reduction defects, the referents with other malformations, and the normal referents.

\begin{tabular}{|c|c|c|c|c|c|c|}
\hline \multirow{3}{*}{ Characteristc } & \multirow{2}{*}{\multicolumn{2}{|c|}{$\begin{array}{l}\text { Cases of limb } \\
\text { reduction defects }\end{array}$}} & \multicolumn{4}{|c|}{ Reference group } \\
\hline & & & \multicolumn{2}{|c|}{ Malformed } & \multicolumn{2}{|c|}{ Normal } \\
\hline & $\mathrm{N}$ & $\%$ & $\mathrm{~N}$ & $\%$ & $\mathrm{~N}$ & $\%$ \\
\hline \multicolumn{7}{|l|}{ Gender } \\
\hline $\begin{array}{l}\text { Male } \\
\text { Female }\end{array}$ & $\begin{array}{l}152 \\
125\end{array}$ & $\begin{array}{l}54.9 \\
45.1\end{array}$ & $\begin{array}{l}177 \\
147\end{array}$ & $\begin{array}{l}54.6 \\
45.4\end{array}$ & $\begin{array}{l}161 \\
166\end{array}$ & $\begin{array}{l}49.2 \\
50.8\end{array}$ \\
\hline \multicolumn{7}{|l|}{ Race } \\
\hline $\begin{array}{l}\text { White } \\
\text { Nonwhite }\end{array}$ & $\begin{array}{r}239 \\
24\end{array}$ & $\begin{array}{r}90.9 \\
9.1\end{array}$ & $\begin{array}{r}289 \\
32\end{array}$ & $\begin{array}{l}90.0 \\
10.0\end{array}$ & $\begin{array}{r}293 \\
32\end{array}$ & $\begin{array}{r}90.1 \\
9.9\end{array}$ \\
\hline \multicolumn{7}{|l|}{ Maternal education (years) } \\
\hline $\begin{array}{r}<12 \\
12 \\
>12\end{array}$ & $\begin{array}{r}47 \\
91 \\
126\end{array}$ & $\begin{array}{l}17.8 \\
34.5 \\
47.7\end{array}$ & $\begin{array}{r}59 \\
132 \\
133\end{array}$ & $\begin{array}{l}18.2 \\
40.7 \\
41.1\end{array}$ & $\begin{array}{r}46 \\
131 \\
150\end{array}$ & $\begin{array}{l}14.1 \\
40.0 \\
45.9\end{array}$ \\
\hline \multicolumn{7}{|l|}{ Maternal age (years) } \\
\hline $\begin{array}{l}\leq 19 \\
20-29 \\
30-34 \\
\geq 35\end{array}$ & $\begin{array}{r}20 \\
161 \\
67 \\
16\end{array}$ & $\begin{array}{r}7.6 \\
61.0 \\
25.4 \\
6.1\end{array}$ & $\begin{array}{r}37 \\
208 \\
59 \\
20\end{array}$ & $\begin{array}{r}11.4 \\
64.2 \\
18.2 \\
6.2\end{array}$ & $\begin{array}{r}30 \\
183 \\
86 \\
28\end{array}$ & $\begin{array}{r}9.2 \\
56.0 \\
26.3 \\
8.6\end{array}$ \\
\hline \multicolumn{7}{|c|}{ Maternal complications during pregnancy* } \\
\hline $\begin{array}{l}\text { Yes } \\
\text { No }\end{array}$ & $\begin{array}{r}40 \\
224\end{array}$ & $\begin{array}{l}15.1 \\
84.8\end{array}$ & $\begin{array}{r}49 \\
258\end{array}$ & $\begin{array}{l}16.0 \\
84.0\end{array}$ & $\begin{array}{r}22 \\
287\end{array}$ & $\begin{array}{r}7.1 \\
92.9\end{array}$ \\
\hline \multicolumn{7}{|l|}{ Preterm (weeks)* } \\
\hline $\begin{array}{l}<37 \\
\geq 37\end{array}$ & $\begin{array}{r}31 \\
226\end{array}$ & $\begin{array}{l}12.1 \\
87.9\end{array}$ & $\begin{array}{r}70 \\
237\end{array}$ & $\begin{array}{l}22.8 \\
77.2\end{array}$ & $\begin{array}{r}26 \\
278\end{array}$ & $\begin{array}{r}8.6 \\
91.4\end{array}$ \\
\hline \multicolumn{7}{|l|}{ Low birth-weight $(\mathrm{g})^{*}$} \\
\hline $\begin{array}{l}<2500 \\
\geq 2500\end{array}$ & $\begin{array}{r}47 \\
227\end{array}$ & $\begin{array}{l}17.1 \\
82.9\end{array}$ & $\begin{array}{r}71 \\
246\end{array}$ & $\begin{array}{l}22.4 \\
77.6\end{array}$ & $\begin{array}{r}20 \\
306\end{array}$ & $\begin{array}{r}6.1 \\
93.9\end{array}$ \\
\hline \multicolumn{7}{|l|}{ Prenatal care } \\
\hline $\begin{array}{l}\text { First trimester } \\
\text { After first trimester } \\
\text { None }\end{array}$ & $\begin{array}{r}207 \\
67 \\
2\end{array}$ & $\begin{array}{r}75.0 \\
24.3 \\
0.7\end{array}$ & $\begin{array}{r}255 \\
67 \\
1\end{array}$ & $\begin{array}{r}79.0 \\
20.7 \\
0.3\end{array}$ & $\begin{array}{r}263 \\
61 \\
2\end{array}$ & $\begin{array}{r}80.7 \\
18.7 \\
0.6\end{array}$ \\
\hline \multicolumn{7}{|l|}{ Previous spontaneous fetal death } \\
\hline $\begin{array}{l}\text { Yes } \\
\text { No }\end{array}$ & $\begin{array}{r}73 \\
204\end{array}$ & $\begin{array}{l}26.3 \\
73.7\end{array}$ & $\begin{array}{r}76 \\
248\end{array}$ & $\begin{array}{l}23.5 \\
76.5\end{array}$ & $\begin{array}{r}65 \\
262\end{array}$ & $\begin{array}{l}19.9 \\
80.1\end{array}$ \\
\hline \multicolumn{7}{|l|}{ Season of first trimester } \\
\hline $\begin{array}{l}\text { Winter (December-February) } \\
\text { Spring (March - May) } \\
\text { Summer (June-August) } \\
\text { Fall (September-November) }\end{array}$ & $\begin{array}{r}116 \\
60 \\
70 \\
31\end{array}$ & $\begin{array}{l}41.9 \\
21.7 \\
25.3 \\
11.2\end{array}$ & $\begin{array}{r}131 \\
83 \\
81 \\
29\end{array}$ & $\begin{array}{r}40.4 \\
25.6 \\
25.0 \\
9.0\end{array}$ & $\begin{array}{r}137 \\
85 \\
67 \\
38\end{array}$ & $\begin{array}{l}41.9 \\
26.0 \\
20.5 \\
11.6\end{array}$ \\
\hline \multicolumn{7}{|l|}{ Maternal residence area ${ }^{\star}$} \\
\hline $\begin{array}{l}\text { Rural } \\
\text { Suburban } \\
\text { Urban }\end{array}$ & $\begin{array}{r}118 \\
87 \\
72\end{array}$ & $\begin{array}{l}42.6 \\
31.4 \\
26.0\end{array}$ & $\begin{array}{r}141 \\
96 \\
87\end{array}$ & $\begin{array}{l}43.5 \\
29.6 \\
26.9\end{array}$ & $\begin{array}{r}134 \\
138 \\
55\end{array}$ & $\begin{array}{l}41.0 \\
42.2 \\
16.8\end{array}$ \\
\hline
\end{tabular}

${ }^{*} \mathrm{P}<0.05$, comparing the distribution of the three groups.

erence group with other malformations was similar to that of the normal referents, we have only presented the comparison between the cases and normal referents.

Paternal or maternal potential occupational exposure to any type of pesticide showed no significant effect on the total risk for limb reduction defects (OR $0.9,95 \%$ CI $0.6-1.4$ ). When we treated housewives, students, or unemployed people as missing rather than as unexposed in the pesticide-exposed analysis, the results were unchanged. However, when the association was examined among associated limb reduction defects and isolated limb reduction defects separately (table 3 ), associated limb reduction defects were positively associated with every type of potential parental exposure to pesticides when they were compared with the normal referents. The OR ranged from 1.1 to 1.9 , but the $95 \%$ confidence intervals included one. This pattern was similar when compared with that of the reference group with other malformations. Paternal occupations exposed to fungicides (OR 1.9, 95\% CI 0.8-4.2) and herbicides (OR 1.9, $95 \%$ CI $0.7-4.8$ ) had higher risks for associated limb reduction defects than those exposed to other pesticides. On the other hand, isolated limb reduction defects were negatively, but not statistically significantly, related to parental occupational pesticide exposures (almost all of the odds ratios were less 
Table 2. Comparison of parental occupation with potential exposure to pesticides among all the cases of limb reduction defect and the normal referents.

\begin{tabular}{|c|c|c|c|c|c|c|}
\hline \multirow{2}{*}{ Parental exposure } & \multicolumn{2}{|c|}{$\begin{array}{l}\text { Cases of limb } \\
\text { reduction defects }\end{array}$} & \multicolumn{2}{|c|}{ Normal referents } & \multirow{2}{*}{$\begin{array}{l}\text { Odds } \\
\text { ratio }\end{array}$} & \multirow{2}{*}{$\begin{array}{c}95 \% \\
\text { confidence } \\
\text { interval }\end{array}$} \\
\hline & $\mathrm{N}$ & $\%$ & $\mathrm{~N}$ & $\%$ & & \\
\hline \multicolumn{7}{|c|}{ Either paternal or maternal exposure } \\
\hline $\begin{array}{l}\text { Disinfectant } \\
\text { Fungicide } \\
\text { Herbicide } \\
\text { Insecticide } \\
\text { Any pesticide }\end{array}$ & $\begin{array}{l}27 \\
20 \\
15 \\
35 \\
36\end{array}$ & $\begin{array}{r}9.8 \\
7.2 \\
5.4 \\
12.6 \\
13.0\end{array}$ & $\begin{array}{l}34 \\
21 \\
15 \\
44 \\
47\end{array}$ & $\begin{array}{r}10.4 \\
6.4 \\
4.6 \\
13.5 \\
14.4\end{array}$ & $\begin{array}{l}0.9 \\
1.1 \\
1.2 \\
0.9 \\
0.9\end{array}$ & $\begin{array}{l}0.6-1.6 \\
0.6-2.1 \\
0.6-2.5 \\
0.6-1.5 \\
0.6-1.4\end{array}$ \\
\hline \multicolumn{7}{|l|}{ Paternal exposure } \\
\hline $\begin{array}{l}\text { Disinfectant } \\
\text { Fungicide } \\
\text { Herbicide } \\
\text { Insecticide } \\
\text { Any pesticide }\end{array}$ & $\begin{array}{l}22 \\
19 \\
14 \\
23 \\
25\end{array}$ & $\begin{array}{r}9.9 \\
8.5 \\
6.3 \\
10.3 \\
9.0\end{array}$ & $\begin{array}{l}26 \\
19 \\
13 \\
29 \\
32\end{array}$ & $\begin{array}{r}9.4 \\
6.9 \\
4.7 \\
10.6 \\
9.8\end{array}$ & $\begin{array}{l}1.0 \\
1.3 \\
1.4 \\
1.0 \\
0.9\end{array}$ & $\begin{array}{l}0.6-1.9 \\
0.6-2.4 \\
0.6-2.9 \\
0.5-1.7 \\
0.5-1.6\end{array}$ \\
\hline \multicolumn{7}{|l|}{ Maternal exposure } \\
\hline $\begin{array}{l}\text { Disinfectant } \\
\text { Fungicide } \\
\text { Herbicide } \\
\text { Insecticide } \\
\text { Any pesticide }\end{array}$ & $\begin{array}{r}8 \\
3 \\
2 \\
13 \\
14\end{array}$ & $\begin{array}{l}3.1 \\
1.2 \\
0.8 \\
5.0 \\
5.0\end{array}$ & $\begin{array}{r}11 \\
5 \\
4 \\
21 \\
22\end{array}$ & $\begin{array}{l}3.6 \\
1.6 \\
1.3 \\
6.8 \\
6.7\end{array}$ & $\begin{array}{l}0.9 \\
0.7 \\
0.6 \\
0.7 \\
0.7\end{array}$ & $\begin{array}{l}0.3-2.2 \\
0.2-3.0 \\
0.1-3.2 \\
0.4-1.5 \\
0.4-1.5\end{array}$ \\
\hline
\end{tabular}

Table 3. Comparison of the parental occupations with potential exposure to pesticides among the cases of associated limb reduction defects and the cases of isolated limb reduction defects with the normal referents.

\begin{tabular}{|c|c|c|c|c|c|c|c|c|}
\hline \multirow[b]{2}{*}{ Parental exposure } & \multicolumn{4}{|c|}{ Associated limb reduction defects ${ }^{a}$} & \multicolumn{4}{|c|}{ Isolated limb reduction defects ${ }^{b}$} \\
\hline & $\mathrm{N}$ & $\%$ & $\begin{array}{l}\text { Odds } \\
\text { ratio }\end{array}$ & $\begin{array}{c}95 \% \\
\text { confidence } \\
\text { interval }\end{array}$ & $\mathrm{N}$ & $\%$ & $\begin{array}{l}\text { Odds } \\
\text { ratio }\end{array}$ & $\begin{array}{c}95 \% \\
\text { confidence } \\
\text { interval }\end{array}$ \\
\hline \multicolumn{9}{|c|}{ Either paternal or maternal exposure } \\
\hline $\begin{array}{l}\text { Disinfectant } \\
\text { Fungicide } \\
\text { Herbicide } \\
\text { Insecticide } \\
\text { Any pesticide }\end{array}$ & $\begin{array}{r}16 \\
11 \\
8 \\
19 \\
20\end{array}$ & $\begin{array}{r}15.4 \\
10.6 \\
7.7 \\
18.3 \\
19.2\end{array}$ & $\begin{array}{l}1.6 \\
1.7 \\
1.7 \\
1.4 \\
1.4\end{array}$ & $\begin{array}{l}0.8-3.0 \\
0.8-3.7 \\
0.7-4.2 \\
0.8-2.6 \\
0.8-2.5\end{array}$ & $\begin{array}{r}11 \\
9 \\
7 \\
16 \\
16\end{array}$ & $\begin{array}{l}6.4 \\
5.2 \\
4.0 \\
9.2 \\
9.2\end{array}$ & $\begin{array}{l}0.6 \\
0.8 \\
0.9 \\
0.7 \\
0.6\end{array}$ & $\begin{array}{l}0.3-1.2 \\
0.4-1.8 \\
0.4-2.2 \\
0.4-1.2 \\
0.3-1.1\end{array}$ \\
\hline \multicolumn{9}{|l|}{ Paternal exposure } \\
\hline $\begin{array}{l}\text { Disinfectant } \\
\text { Fungicide } \\
\text { Herbicide } \\
\text { Insecticide } \\
\text { Any pesticide }\end{array}$ & $\begin{array}{r}12 \\
10 \\
7 \\
13 \\
14\end{array}$ & $\begin{array}{r}14.6 \\
12.2 \\
8.5 \\
15.9 \\
13.5\end{array}$ & $\begin{array}{l}1.6 \\
1.9 \\
1.9 \\
1.6 \\
1.4\end{array}$ & $\begin{array}{l}0.8-3.4 \\
0.8-4.2 \\
0.7-4.8 \\
0.8-3.2 \\
0.7-2.8\end{array}$ & $\begin{array}{r}10 \\
9 \\
7 \\
10 \\
11\end{array}$ & $\begin{array}{l}7.1 \\
6.4 \\
5.0 \\
7.1 \\
6.4\end{array}$ & $\begin{array}{l}0.7 \\
0.9 \\
1.1 \\
0.6 \\
0.6\end{array}$ & $\begin{array}{l}0.3-1.6 \\
0.4-2.1 \\
0.4-2.7 \\
0.3-1.4 \\
0.3-1.3\end{array}$ \\
\hline \multicolumn{9}{|l|}{ Maternal exposure } \\
\hline $\begin{array}{l}\text { Disinfectant } \\
\text { Fungicide } \\
\text { Herbicide } \\
\text { Insecticide } \\
\text { Any pesticide }\end{array}$ & $\begin{array}{l}5 \\
2 \\
2 \\
7 \\
7\end{array}$ & $\begin{array}{l}5.2 \\
2.1 \\
2.1 \\
7.3 \\
6.7\end{array}$ & $\begin{array}{l}1.5 \\
1.3 \\
1.6 \\
1.1 \\
1.0\end{array}$ & $\begin{array}{l}0.5-4.4 \\
0.2-6.8 \\
0.3-8.9 \\
0.4-2.6 \\
0.4-2.4\end{array}$ & $\begin{array}{l}3 \\
1 \\
0 \\
6 \\
7\end{array}$ & $\begin{array}{l}1.8 \\
0.6 \\
0.0 \\
3.7 \\
4.0\end{array}$ & $\begin{array}{l}0.5 \\
0.4 \\
0 \\
0.5 \\
0.6\end{array}$ & $\begin{array}{l}0.1-1.8 \\
0.0-3.0 \\
0.2-1.3 \\
0.2-1.4\end{array}$ \\
\hline
\end{tabular}

a Associated limb reduction defects: the cases with at least one additional malformation.

b Isolated limb reduction defects: the cases without any other malformations.

c All of the odds ratios were calculated from comparisons of the cases of associated limb reduction defects $(N=104)$ or the isolated limb reduction defects $(N=173)$ with the normal referents $(N=327)$.

than one). These differences and trends consistently appeared for each type of pesticide and for both paternal and maternal exposure. The most common associated malformations (other than limb reduction defects) in the current study were upper limb malformations $(\mathrm{N}=50)$, musculoskeletal defects $(\mathrm{N}=$ $30)$, lower limb defects $(\mathrm{N}=29)$, and genitourinary malformations $(\mathrm{N}=27)$.

Comparisons of parental farming occupations among different categories of limb reduction defects including all limb reduction defects, associated limb reduction defects, and isolated limb reduction defects, to those of normal referents (table 4) showed a pattern similar to that of other occupations. If all of the cases of limb reduction defects were compared with normal referents, having a parent involved in farming did not increase the risk of limb reduction defects. However, parents in farming occupations tended to show increased nonsignificant risks of associated limb reduction defects (OR 2.0, 95\% CI 
Table 4. Comparison of the parental occupations involved in agriculture among all the cases of limb reduction defects, the cases of associated limb reduction defects, the cases of isolated limb reduction defects and the normal referents.

\begin{tabular}{|c|c|c|c|c|c|c|}
\hline \multirow{2}{*}{ Parental exposure } & \multicolumn{2}{|c|}{ Cases } & \multicolumn{2}{|c|}{ Normal referents } & \multirow{2}{*}{$\begin{array}{l}\text { Odds } \\
\text { ratio }\end{array}$} & \multirow{2}{*}{$\begin{array}{c}95 \% \\
\text { confidence } \\
\text { interval }\end{array}$} \\
\hline & $\mathrm{N}$ & $\%$ & $N$ & $\%$ & & \\
\hline \multicolumn{7}{|c|}{ All limb reduction defects $(N=277)$} \\
\hline $\begin{array}{l}\text { Either parent farmer } \\
\text { Paternal farmer } \\
\text { Maternal farmer }\end{array}$ & $\begin{array}{r}11 \\
10 \\
2\end{array}$ & $\begin{array}{l}6.0 \\
5.0 \\
0.8\end{array}$ & $\begin{array}{r}12 \\
11 \\
5\end{array}$ & $\begin{array}{l}5.2 \\
4.4 \\
1.8\end{array}$ & $\begin{array}{l}1.1 \\
1.1 \\
0.5\end{array}$ & $\begin{array}{l}0.5-2.7 \\
0.5-2.7 \\
0.1-2.3\end{array}$ \\
\hline \multicolumn{7}{|c|}{ Associated limb reduction defects $(N=104)$} \\
\hline $\begin{array}{l}\text { Either parent farmer } \\
\text { Paternal farmer } \\
\text { Maternal farmer }\end{array}$ & $\begin{array}{l}7 \\
6 \\
2\end{array}$ & $\begin{array}{r}10.0 \\
7.9 \\
2.3\end{array}$ & $\begin{array}{r}12 \\
11 \\
5\end{array}$ & $\begin{array}{l}5.2 \\
4.4 \\
1.8\end{array}$ & $\begin{array}{l}2.0 \\
1.8 \\
1.3\end{array}$ & $\begin{array}{l}0.7-5.3 \\
0.7-5.1 \\
0.2-6.7\end{array}$ \\
\hline \multicolumn{7}{|c|}{ Isolated limb reduction defects $(N=173)$} \\
\hline $\begin{array}{l}\text { Either parent farmer } \\
\text { Paternal farmer } \\
\text { Maternal farmer }\end{array}$ & $\begin{array}{r}4 \\
4 \\
-\end{array}$ & $\begin{array}{l}3.5 \\
3.2 \\
0.0\end{array}$ & $\begin{array}{r}12 \\
11 \\
1\end{array}$ & $\begin{array}{l}5.2 \\
4.4 \\
0.3\end{array}$ & $\begin{array}{l}0.7 \\
0.7 \\
0\end{array}$ & $\begin{array}{l}0.2-2.1 \\
0.2-2.3\end{array}$ \\
\hline
\end{tabular}

0.7-5.3). Similar to the potential occupational pesticide exposures, parental farming occupations appeared to be negatively related to isolated limb reduction defects (OR 0.7).

Table 5 displays the comparison between county agricultural activity or county pesticide use among the cases of limb reduction defects (including all limb reduction defects and associated limb reduction defects) and the malformed or normal referents. There were no associations between maternal residence in a farming county (farmland acres per capita) or in a county with high pesticide (fungicide, herbicide, insecticide or nematicide) use in that county and risk of limb reduction defects or associated limb reduction defects. The effects of high county-wide exposure to multiple pesticides were demonstrated with the use of summary scores, as shown in table 5 . There were no significant differences in the risk for limb reduction defects among those with low exposure, single exposures, or multiple exposures.

We attempted to control for confounding effects using multivariate logistic regression. However, the potentially etiologic variables, like maternal complications, or population density (rural, suburban or urban area) were not significantly related to the risk for limb reduction defects and did not alter the exposure odds ratios. Furthermore, exposure variables such as parental involvement in farming or potential pesticide-related occupations were not significantly related to each other or to population density. Thus the regression analysis did not contribute further information, and the results were very similar to those of the crude analyses.

\section{Discussion}

In contrast to the positive findings of Kricker et al (13), our findings indicated that there was no significant positive association between parental farming occupations and potentially pesticide-exposed occupations and overall limb reduction defects. Howev- er, when we separated all limb reduction defect cases into two groups (associated limb reduction defects and isolated limb reduction defects), the associated cases showed a consistently positive association with parental involvement in either pesticide-exposed work or agricultural occupations. This finding agrees with Schwartz \& LoGerfo's finding (11). Unexpectedly, however, isolated cases seemed to have negative associations with potential parental exposure to pesticide through occupation. Although this difference may be caused by chance or by the misclassification of exposure, our study suggested that the etiology of associated limb reduction defects may be different from those of isolated limb reduction defects. Several previous studies $(26-28)$ indicate that an increased malformation risk due to environmental or drug exposures may be manifest as an excess of infants born with a combination of distinctive defects. A previous analysis of this case group (29) found that the cases of associated limb reduction defects had other distinctive characteristics. They were more likely to have suspected syndromes, amniotic bands, associated syndactyly, low birthweight, or major limb reductions when compared with singlelimb isolated cases of limb reduction defect. Thus associated limb reduction defects may have distinct etiologic patterns. However, from a biological point of view, it is unclear why associated limb reduction defects tended to be positively associated with all types of pesticides, while isolated limb reduction defects were negatively associated. Another explanation for our results may be that the referral reporting patterns might be different between isolated and associated limb reduction defects and that this difference might lead to a variation in the classification of exposure. For example, reporting should be more complete for complex associated cases than less obvious isolated cases with fewer medical needs. However, it is difficult to evaluate this possibility from the available data.

The prevalence rate of limb reduction defects in the current study $(0.45$ per 1000$)$ was close to the 
Table 5. Comparison of county pesticide use and agricultural activity between the cases of limb reduction defects and the referents. ${ }^{a}$

\begin{tabular}{|c|c|c|c|c|c|c|c|c|c|c|c|}
\hline \multirow{3}{*}{ Exposure category } & \multicolumn{9}{|c|}{ Relative exposure } & & \multirow{3}{*}{ P-value } \\
\hline & \multicolumn{2}{|c|}{ Low } & & \multicolumn{3}{|c|}{ Medium } & \multicolumn{3}{|c|}{ High } & & \\
\hline & $\mathrm{N}$ & $\%$ & & $\mathrm{~N}$ & T & $\%$ & & $\sqrt{ }$ & $\%$ & & \\
\hline \multicolumn{12}{|c|}{ Farmland acres per capita } \\
\hline $\begin{array}{l}\text { All cases } \\
\text { Associated cases } \\
\text { Malformed referents } \\
\text { Normal referents }\end{array}$ & $\begin{array}{r}8 \\
\frac{7}{13}\end{array}$ & $\begin{array}{l}6.7 \\
0.0 \\
5.0 \\
9.7\end{array}$ & & $\begin{array}{l}46 \\
19 \\
50 \\
50\end{array}$ & $\begin{array}{l}3 \\
4 \\
3 \\
3\end{array}$ & $\begin{array}{l}3.7 \\
4.2 \\
5.5 \\
7.3\end{array}$ & & $\begin{array}{l}5 \\
4 \\
4 \\
1\end{array}$ & $\begin{array}{l}54.6 \\
55.8 \\
59.6 \\
53.0\end{array}$ & & $\begin{array}{l}0.56 \\
0.15\end{array}$ \\
\hline \multicolumn{12}{|l|}{ County fungicide use } \\
\hline $\begin{array}{l}\text { All cases } \\
\text { Associated cases } \\
\text { Malformed referents } \\
\text { Normal referents }\end{array}$ & $\begin{array}{l}65 \\
22 \\
76 \\
67\end{array}$ & $\begin{array}{l}54.6 \\
51.2 \\
53.9 \\
50.0\end{array}$ & & $\begin{array}{l}35 \\
13 \\
46 \\
36\end{array}$ & $\begin{array}{l}2 \\
3 \\
3 \\
2\end{array}$ & $\begin{array}{l}0.4 \\
0.2 \\
2.6 \\
. .9\end{array}$ & & $\begin{array}{l}9 \\
8 \\
9 \\
1\end{array}$ & $\begin{array}{l}16.0 \\
18.6 \\
13.5 \\
23.1\end{array}$ & & $\begin{array}{l}0.29 \\
0.34\end{array}$ \\
\hline \multicolumn{12}{|l|}{ County herbicide use } \\
\hline $\begin{array}{l}\text { Alf cases } \\
\text { Associated cases } \\
\text { Malformed referents } \\
\text { Normal referents }\end{array}$ & $\begin{array}{l}43 \\
16 \\
58 \\
41\end{array}$ & $\begin{array}{l}36.1 \\
37.2 \\
41.1 \\
30.6\end{array}$ & & $\begin{array}{l}44 \\
18 \\
45 \\
56\end{array}$ & $\begin{array}{l}3 \\
4 \\
3 \\
4\end{array}$ & $\begin{array}{l}7.0 \\
1.9 \\
1.9 \\
1.8\end{array}$ & & $\begin{array}{l}2 \\
9 \\
8 \\
7\end{array}$ & $\begin{array}{l}26.9 \\
20.9 \\
27.0 \\
27.6\end{array}$ & & $\begin{array}{l}0.41 \\
0.31\end{array}$ \\
\hline \multicolumn{12}{|l|}{ County insecticide use } \\
\hline $\begin{array}{l}\text { All cases } \\
\text { Associated cases } \\
\text { Malformed referents } \\
\text { Normal referents }\end{array}$ & $\begin{array}{l}65 \\
23 \\
83 \\
62\end{array}$ & $\begin{array}{l}54.6 \\
53.5 \\
58.9 \\
46.3\end{array}$ & & $\begin{array}{r}32 \\
9 \\
33 \\
41\end{array}$ & $\begin{array}{l}2 \\
2 \\
2 \\
30\end{array}$ & $\begin{array}{l}3.9 \\
0.9 \\
3.4 \\
0.6\end{array}$ & & $\begin{array}{l}2 \\
1 \\
5 \\
1\end{array}$ & $\begin{array}{l}18.5 \\
25.6 \\
17.7 \\
23.1\end{array}$ & & $\begin{array}{l}0.33 \\
0.25\end{array}$ \\
\hline \multicolumn{12}{|l|}{ County nematicide use } \\
\hline $\begin{array}{l}\text { All cases } \\
\text { Associated cases } \\
\text { Malformed referents } \\
\text { Normal referents }\end{array}$ & $\begin{array}{r}26 \\
9 \\
36 \\
37\end{array}$ & $\begin{array}{l}21.9 \\
20.9 \\
25.5 \\
27.6\end{array}$ & & $\begin{array}{l}51 \\
17 \\
62 \\
49\end{array}$ & $\begin{array}{l}4 \\
3 \\
4 \\
3\end{array}$ & $\begin{array}{l}2.9 \\
3.5 \\
4.0 \\
6.6\end{array}$ & & $\begin{array}{l}2 \\
7 \\
3 \\
8\end{array}$ & $\begin{array}{l}35.3 \\
39.5 \\
30.5 \\
35.8\end{array}$ & & $\begin{array}{l}0.63 \\
0.64\end{array}$ \\
\hline \multirow{3}{*}{ Normal referents } & \multicolumn{11}{|c|}{ Score } \\
\hline & \multicolumn{2}{|c|}{0} & \multicolumn{2}{|c|}{1} & \multicolumn{2}{|r|}{2} & \multicolumn{2}{|c|}{3} & \multicolumn{2}{|c|}{4} & \\
\hline & $N$ & $\%$ & $\mathrm{~N}$ & $\%$ & $\mathrm{~N}$ & $\%$ & $\mathrm{~N}$ & $\%$ & $\mathrm{~N}$ & $\%$ & \\
\hline \multicolumn{12}{|l|}{ Multiple county pesticide } \\
\hline $\begin{array}{l}\text { Afl cases } \\
\text { Associated cases } \\
\text { Malformed referents } \\
\text { Normal referents }\end{array}$ & $\begin{array}{l}47 \\
16 \\
70 \\
48\end{array}$ & $\begin{array}{l}42.7 \\
40.0 \\
51.8 \\
38.7\end{array}$ & $\begin{array}{r}25 \\
8 \\
19 \\
28\end{array}$ & $\begin{array}{l}22.7 \\
20.0 \\
14.1 \\
22.6\end{array}$ & $\begin{array}{l}30 \\
13 \\
37 \\
37\end{array}$ & $\begin{array}{l}27.3 \\
32.5 \\
27.4 \\
29.8\end{array}$ & $\begin{array}{l}2 \\
1 \\
4 \\
3\end{array}$ & $\begin{array}{l}1.8 \\
2.5 \\
3.0 \\
2.4\end{array}$ & $\begin{array}{l}6 \\
2 \\
5 \\
8\end{array}$ & $\begin{array}{l}5.4 \\
5.0 \\
3.7 \\
6.4\end{array}$ & $\begin{array}{l}0.5 \\
0.4\end{array}$ \\
\hline
\end{tabular}

findings of other studies $(0.48-0.49$ per 1000) (30-32). In terms of occupational exposure frequency, there were $4.8 \%$ parents (either paternal or maternal) involved in farming occupations, and this figure is lower than the $6.9 \%$ in Schwartz \& LoGerfo's study (11). But since California has more agricultural activity than New York State, the frequency of farming occupations was understandably lower. Our study also found that $10.1 \%$ of employed women had potential pesticide exposure, comparable with the findings of Kricker et al's study in Wales, in which $13.1 \%$ of the women were exposed to pesticides at the workplace according to the interview (13).

There are several limitations of our occupational exposure assessment. First, there was a higher proportion of missing paternal occupations (14.4\%) than maternal occupations $(1.7 \%)$ on the birth certificates. Furthermore, the mothers coded on the birth certifi- cates in this study as homemakers or unemployed during pregnancy $(40 \%)$ might have actually been exposed during pregnancy or prior to conception. According to a recent study conducted by Marshall et al (33) in upstate New York, $28 \%$ of the occupations and $23 \%$ of the industries listed on the birth certificates were not the same as what the mother reported via a questionnaire describing her first trimester job. The majority of these circumstances $(75 \%)$ disagreed on whether or not the mother worked outside the home during the periconceptional period (33). There was no difference in either the validity or rate of missing data between malformed cases and normal referents. Paternal occupations were more often missing, but they were more likely to be accurate than the maternal occupations were (34). Thus previous research shows that using the information from birth certificates for parental occupations will initiate nondifferential misclassification of exposure. 
Second, industrial hygienists assessed potential exposure based on job title and industry, and no actual data on exposure were available. This procedure would also generate further nondifferential misclassification. Third, because the job titles were often rated as having more than one type of pesticide exposure, it is difficult to separate the independent effects of each type. Finally, the relatively low percentage of farmers or jobs potentially exposed to pesticides in this study, especially among the mothers, leads to low study power. All these limitations may have lowered the power of the study to find a significant difference.

Unlike two previous studies $(7,11)$, the current investigation did not find an association between maternal residence in an agricultural county or high pesticide-use county and the risk of congenital malformations among their children. In contrast with the results for occupation, there was no difference in risk between the cases of associated limb reduction defects and isolated limb reduction defects when compared with normal referents. In addition, our study found that parental occupational pesticide exposure was not related to maternal residence in counties with high agricultural use of pesticides. Although we used a combination indicator for multiple pesticide exposures at the county level, the number of chemicals involved was not related to the risk of limb reduction defects. The difference between these results and others may be explained by differences in pesticide uses, types, and frequencies. The results may also suggest that county pesticide use is not a good indicator of maternal exposure to pesticides during pregnancy or prior to conception or is not a good indicator of individual exposure or that there is no effect of residential exposure on the risk for limb reduction defects. The limitations of utilizing ecological data by applying county level data to individual exposure are well known and have been presented by other studies $(35,36)$.

The current study revealed that the limb reduction defect cases and the referents with other malformations had significantly higher proportions of residents of urban areas and lower proportions of suburban residents than the normal referents did. However, the proportion reporting rural residence was the same among the cases, the referents with other malformations, and the normal referents. There may be two possible interpretations of this difference. First, selective reporting of malformations may occur in different areas. In other words, there may be more complete reporting of malformations in the most urban areas compared with the reporting in other areas. Second, if the differences in residential areas between the cases and the normal referents are true, then there might be unknown risk factors for limb reduction and other defects present in urban areas. When the cases were compared with the referents with other malformations instead of normal referents, our occupational results did not change. This finding suggests that variables such as maternal race, education, and age that are typically associated with population density or type of residential area did not alter the comparisons. Associated limb reduction defects, but not other malformations, were related to parental occupational pesticide exposure.

Our study also indicated that the occurrence of maternal complications during pregnancy, preterm delivery, and children with low birthweights were positively associated with the cases of limb reduction defects when compared with normal referents. This finding agrees with those of most previous studies $(37-40)$. Since there were no significantly different rates of low birthweights between major or severe limb reduction defects (proximal and long bone missing or reduction, $13.9 \%$ ) and minor limb reduction defects (distal or phalange reduction, $12.2 \%$ ), it is unlikely that infants with low birthweights are low in weight due to the lack of a limb. In addition, the referents with malformations other than reduction defects had a higher rate $(22.4 \%)$ of low birthweight than that of the cases of limb reduction defects $(17.1 \%)$. We found that limb reduction defects with multiple limbs involved had a much higher rate of low birthweight $(20 \%)$ than those with a single limb involved (10\%), a finding suggesting that low birthweight may be related to multiple developmental defects.

This study is one of the few studies to use industrial hygienists' assessments to explore all possible combinations of pesticide-exposed industries and occupations rather than just farming. Previous studies using parental farming as the sole source of pesticide exposure might have resulted in incomplete exposure assessment because many other occupations are also potentially exposed to pesticides. Therefore, this study improved exposure assessment, even though substantial misclassification might have remained. In addition, case ascertainment was population-based, and the diagnoses of all the cases were reviewed and verified. The current study also separated the possible effects of exposure on the risk of associated limb reduction defects from the risk of isolated limb reduction defects, suggesting a new clue for future studies. Finally, although not statistically significant, the study showed a suggestive trend of an association between potential parental exposure to pesticides and associated limb reduction defects. We would encourage future studies to use more complete and individually accurate exposure assessments and to treat isolated and associated limb reduction defects separately.

\section{Acknowledgments}

The authors thank Dr J Melius, Dr A Stark, and Dr E Fitzgerald for their valuable comments on the manuscript; Mr W Burke, Mr R DePersis, Mr M Lon- 
don, and Dr M Gadon for their help with the exposure assessment; Ms L Gensburg for her statistical advice, and Ms G Roth for her assistance in preparing the manuscript.

\section{References}

1. Lin S, Marshall EG, Davidson GK, Roth GB, Druschel CM. Evaluation of congenital limb reduction defects in upstate New York. Teratology 1993;47:127-35.

2. Hayes WJ. Toxicology of pesticides. Baltimore, MD: Williams and Wilkins Co, 1975.

3. Food and Agricultural Organization (FAO). Pesticide residues in food 1982 evaluations: plant production and protection paper 49, Rome: FAO, 1983:1-427.

4. Townsend J, Bodner K, Van Peenen P, Olson R. Survey of reproductive events of wives of employees exposed to chlorinated dioxins. Am J Epidemiol 1982; 115:695-713.

5. Longo L. Environmental pollution and pregnancy: risks and uncertainties for the fetus and infant. Am J Obst Gynecol 1980;137:162-73.

6. Balarajan R, McDowall M. Congenital malformations and agricultural workers. Lancet 1983;1:1392.

7. Gordon JE, Shy CM. Agricultural chemical use and congenital cleft lip and/or palate. Arch Environ Health 1981;36(5):213-21.

8. White FMM, Cohen FG, Sherman G, McCurdy R. Chemicals, birth defects and stillbirths in New Brunswick: associations with agricultural activity. Can Med Assoc J 1988; 138:117-24.

9. Mohan D. Food vs limbs, pesticides and physical disability in India. Econ Polit Wkly 1987; XXII(13):A$23-9$.

10. Schwartz DA, Newsum LA, Markowitz Heifetz R. Parental occupation and birth outcome in an agricultural community. Scand J Work Environ Health 1986; $12: 51-4$

11. Schwartz DA, LoGerfo JP. Congenital limb reduction defects in the agricultural setting. Am J Public Health 1988;78(6):654-9.

12. Munger RG, Isacson $P$, Kramer M, Hanson J, Burns $\mathrm{T}$, Cherryholmes $\mathrm{K}$, et al. Birth defects and pesticidecontaminated water supplies in Iowa. Am J Epidemiol 1992;136(8):959.

13. Kricker A, McCredie J, Elliott J, Forrest J. Women and the environment: a study of congenital limb anomalies. Community Health Stud 1986;10(1):1-11.

14. Roan CC, Matanoski GE, McIlnay CQ, Oldis KL, Pylant F, Tront JR, et al. Spontaneous abortions, stillbirths and birth defects in families of agricultural pilots. Arch Environ Health 1984;39:56-60.

15. Hemminki K, Mutanen P, Luoma K, Saloniemi I. Congenital malformations by the parental occupation in Finland. Int Arch Occup Environ Health 1980;46:938.

16. Hunt VR. Reproductive toxicology. Presented at the Conference on Pesticide and Human Health, Washington, DC 1978.

17. New York State Department of Health. Congenital malformations registry annual report: 1984 birth cohort. Albany, NY: New York State Department of Health, 1984.

18. US Department of Health and Human Services, Public Health Service - Health Care Financing Administration. The international classification of diseases; vol 1,2, and 3.9th revision, second edition. Pittsburgh, PA: United States Department of Health and Human Services, 1980.

19. Birth Defect Monitoring Program (BDMP), Centers for Disease Control (CDC). Defects to be included in routine BDMP monitoring. In: BDMP monitoring propos- al. Atlanta, GA: CDC, 1987:25.

20. New York State Department of Health. Vital statistics of New York State. Albany, NY: New York State Department of Health, 1987.

21. United States Department of Commerce, Bureau of the Census. 1987 census of agriculture; vol 1 (Geographic area series, part 32, New York, state and county data). Washington, DC: United States Government Printing Office, 1987.

22. United States Department of Commerce. Classification index of occupation and industry. Washington, DC: Government Printing Office, 1980.

23. Carucci PM. Reliability of statistical and medical information reported on birth and death certificates. Albany, NY: New York Department of Health, 1979. (New York Department of Health monograph; no 15.)

24. Taylor JR, Selhorst JB, Houff SA, Martinez AJ. Chlordecone intoxication in man: I. clinical observations. Neurology 1978;28:626-30.

25. Schraders, Turner T, Ratcliffe J. The effects of ethylene dibromide on semen quality: a comparison of short-term and chronic exposure. Reprod Toxicol 1988;2:191.

26. Schardein JL. Chemically induced birth defects. New York, NY: Marcel Dekker, Inc, 1985.

27. Sever JL, Brent RL, ed. Teratogen update: environmentally induced birth defects risks. New York, NY: Alan R Liss, Inc, 1986.

28. Smith DW. Recognizable patterns of human malformations. 3rd ed. Philadelphia, PA: WB Saunders Company, 1982.

29. Marshall EG, Lin S, Gensburg L, Druschel C. A comparison of limb reduction defects with and without other malformations. Am J Epidemiol 1992;136(8): $1010-1$.

30. Calzolari E, Manservigi D, Garani GP. Limb reduction defects in Emilia Romagna, Italy: epidemiological and genetic study in 173109 consecutive births. J Med Genet 1990;27:353-7.

31. Bod M, Czeizel A, Lenz W. Incidence at birth of different types of limb reduction abnormalities in Hungary 1975-7. Hum Genet 1983;65:27-33.

32. United States Department of Health and Human Services, Public Health Service, Center for Disease Control (CDC). Congenital malformations surveillance report: January 1982 - December 1985, issued March 1988. Atlanta, GA: CDC, 1988.

33. Marshall EG, Gensburg LJ, Roth GB, Davidson GK. Comparison of mother's occupation and industry from the birth certificate and a self-administered questionnaire. J Occup Med 1992;34(11):1090-6.

34. Shaw GM, Malcoe LH, Croen LA, Smith DF. An assessment of error in parental occupation from the birth certificate. Am J Epidemiol 1990;131:1072-9.

35. Bogue DJ, Bogue EJ. Essays in human ecology. Chicago, IL: University of Chicago (Community and Family Study Center), 1976.

36. Stavraky $\mathrm{K}$. The role of ecologic analysis in studies of the etiology of disease: a discussion with reference to large bowel cancer. J Chronic Dis 1976;29:435-44.

37. Polednak AP, Janerich DT. Maternal factors in congenital limb-reduction defects. Teratology $1985 ; 32$ : $41-50$.

38. Rogala EJ, Wynne-Davies R, Littlejohn A, Gormley J. Congenital limb anomalies: frequency and etiological factors. J Med Genet 1974;11:221-33.

39. Calzolari E, Manservigi D, Garani GP, Cocchi G, Magnani C, Milan M, et al. Limb reduction defects in Emilia Romagna, Italy: epidemiological and genetic study in 173109 consecutive births. J Med Genet $1990 ; 27: 353-7$.

40. Stoll C, Alembik Y, Dott B, Roth MP. Risk factors in limb reduction defects. Pediatr Perinatal Epidemiol 1992;6:323-38. 


\section{Appendix 1}

\section{All potential paternal pesticide exposures based on the industrial hygienists' assessments}

\begin{tabular}{|c|c|c|c|c|c|c|c|}
\hline \multicolumn{2}{|c|}{ Industry code } & \multicolumn{2}{|c|}{ Occupational code } & \multirow{2}{*}{$\begin{array}{c}\begin{array}{c}\text { Disinfec- } \\
\tan ^{\mathrm{a}}\end{array} \\
1\end{array}$} & \multirow{2}{*}{$\frac{\text { Fungicide }^{a}}{1}$} & \multirow{2}{*}{$\frac{\text { Herbicide }^{\mathrm{a}}}{1}$} & \multirow{2}{*}{$\frac{\begin{array}{r}\text { Insecti- } \\
\text { cide }^{\mathrm{a}}\end{array}}{1}$} \\
\hline & $\ldots \ldots$ & 444 & Miscellaneous food occupations & & & & \\
\hline & $\ldots \ldots$ & 486 & Groundskeepers, gardeners & 1 & 1 & 1 & 1 \\
\hline & $\ldots \ldots$ & 453 & Janitors & 1 & 1 & 1 & 1 \\
\hline & $\ldots \ldots$ & 486 & Groundskeepers, gardeners & 1 & 1 & 1 & 1 \\
\hline & $\ldots \ldots$ & 686 & Butchers and meat cutters & 1 & 1 & 1 & 1 \\
\hline 010 & $\begin{array}{l}\text { Agriculture, production } \\
\text { crops }\end{array}$ & 473 & Farmers & 0 & 1 & 1 & 1 \\
\hline 010 & $\begin{array}{l}\text { Agriculture, production } \\
\text { crops }\end{array}$ & 479 & Farm workers & 0 & 1 & 1 & 1 \\
\hline 011 & Livestock & 473 & Farmers & 1 & 1 & 1 & 1 \\
\hline 011 & Livestock & 479 & Farm workers & 1 & 1 & 1 & 1 \\
\hline 021 & Horticultural & 486 & Groundskeepers, gardeners & 0 & 1 & 1 & 1 \\
\hline 060 & Construction & 869 & Personal care occupations & 0 & 1 & 1 & 1 \\
\hline 101 & $\begin{array}{l}\text { Manufacturing, dairy } \\
\text { products }\end{array}$ & 243 & Sales superisors and proprietors & 1 & 0 & 0 & 0 \\
\hline 101 & $\begin{array}{l}\text { Manufacturing, dairy } \\
\text { products }\end{array}$ & 453 & Janitors & 1 & 1 & 1 & 1 \\
\hline 101 & $\begin{array}{l}\text { Manufacturing, dairy } \\
\text { products }\end{array}$ & 804 & Truck drivers (heavy) & 1 & 0 & 0 & 0 \\
\hline 101 & $\begin{array}{l}\text { Manufacturing, dairy } \\
\text { products }\end{array}$ & 889 & Laborer, except construction & 1 & 1 & 0 & 1 \\
\hline 112 & $\begin{array}{l}\text { Manufacturing, sugar and } \\
\text { confections }\end{array}$ & 889 & Laborers, except construction & 1 & 0 & 0 & 1 \\
\hline 120 & Beverage industry & 633 & Superisors production occupations & 1 & 0 & 0 & 1 \\
\hline 160 & Pulp and paper mills & 544 & Millwrights & 1 & 1 & 0 & 0 \\
\hline 160 & Pulp and paper mills & 777 & Miscellaneous machine operators & 1 & 1 & 0 & 0 \\
\hline 230 & Logging & 496 & Timbercutters, loggers & 1 & 1 & 1 & 1 \\
\hline 231 & $\begin{array}{l}\text { Sawmills, planing mills, } \\
\text { millwork }\end{array}$ & 727 & Sawing machine operators & 1 & 1 & 1 & 1 \\
\hline 231 & $\begin{array}{l}\text { Sawmills, planing mills, } \\
\text { millwork }\end{array}$ & 889 & Laborers, except construction & 1 & 1 & 1 & 1 \\
\hline 242 & Furniture & 779 & Machine operator & 1 & 1 & 0 & 0 \\
\hline 250 & Glass production & 883 & Freight, stock handlers & 0 & 0 & 0 & 1 \\
\hline 270 & Steelworks & 453 & Janitors & 1 & 1 & 1 & 1 \\
\hline 281 & $\begin{array}{l}\text { Cutlery, hand tools, } \\
\text { hardware }\end{array}$ & 544 & Millwrights & 1 & 1 & 0 & 0 \\
\hline 290 & Screw machine products & 637 & Machinist & 1 & 1 & 0 & 0 \\
\hline 290 & Screw machine products & 777 & Miscellaneous machine operators & 1 & 1 & 0 & 0 \\
\hline 290 & Screw machine products & 889 & Laborers, except construction & 1 & 1 & 0 & 0 \\
\hline 291 & Metal forging, stamping & 779 & Machine operators & 1 & 1 & 0 & 0 \\
\hline 300 & $\begin{array}{l}\text { Miscellaneous fabricating, } \\
\text { metals }\end{array}$ & 453 & Janitors & 1 & 1 & 1 & 1 \\
\hline 400 & Transportation, railroad & & $\ldots$ & 1 & 1 & 1 & 1 \\
\hline 400 & Transportation, railroad & 889 & Laborers, except construction & 1 & 1 & 1 & 1 \\
\hline 420 & Water transportation & 876 & Stevedores & 1 & 1 & 1 & 1 \\
\hline 441 & Telephone company & 453 & Janitors & 1 & 1 & 1 & 1 \\
\hline 460 & Electric lights and power & 366 & Meter readers & 1 & 1 & 1 & 1 \\
\hline 460 & Electric lights and power & 575 & Electricians & 1 & 1 & 1 & 1 \\
\hline 461 & Gas, steam supply & & $\ldots$ & 1 & 1 & 1 & 1 \\
\hline 461 & Gas, steam supply & 036 & Inspectors & 1 & 1 & 1 & 1 \\
\hline 462 & Electric and gas combined & & $\ldots \ldots$ & 1 & 1 & 1 & 1 \\
\hline 462 & Electric and gas combined & 796 & $\begin{array}{l}\text { Production checkers, examiners } \\
\text { and inspectors }\end{array}$ & 0 & 0 & 0 & 1 \\
\hline 471 & Sanitary service & & $\ldots$ & 1 & 1 & 1 & 1 \\
\hline 471 & Sanitary service & 875 & Garbage collectors & 1 & 1 & 1 & 1 \\
\hline 471 & Sanitary service & 887 & Vehicle equipment washers & 1 & 1 & 0 & 1 \\
\hline 550 & $\begin{array}{l}\text { Groceries and related } \\
\text { products, wholesale }\end{array}$ & & $\ldots$ & 1 & 1 & 1 & 1 \\
\hline 550 & $\begin{array}{l}\text { Groceries and related } \\
\text { products, wholesale }\end{array}$ & 243 & Sales, supervisors & 0 & 0 & 0 & 1 \\
\hline
\end{tabular}


Appendix 1. Continued

\begin{tabular}{|c|c|c|c|c|c|c|c|}
\hline \multicolumn{2}{|c|}{ Industry code } & \multicolumn{2}{|c|}{ Occupational code } & \multirow{2}{*}{$\frac{\begin{array}{c}\text { Disinfec- } \\
\tan ^{\mathrm{a}}\end{array}}{1}$} & \multirow{2}{*}{$\frac{\text { Fungicide }^{a}}{1}$} & \multirow{2}{*}{$\frac{\text { Herbicide }^{a}}{0}$} & \multirow{2}{*}{$\frac{\begin{array}{c}\text { Insecti- } \\
\text { cide }^{\mathrm{a}}\end{array}}{0}$} \\
\hline 550 & $\begin{array}{l}\text { Groceries and related } \\
\text { products, wholesale }\end{array}$ & 768 & $\begin{array}{l}\text { Crushing and grinding machine } \\
\text { operators }\end{array}$ & & & & \\
\hline 550 & $\begin{array}{l}\text { Groceries and related } \\
\text { products, wholesale }\end{array}$ & 804 & Truck drivers (heavy) & 1 & 1 & 0 & 1 \\
\hline 582 & Retail, garden products & 804 & Truck drivers (heavy) & 1 & 1 & 0 & 1 \\
\hline 591 & Department store & 453 & Janitors & 1 & 0 & 0 & 1 \\
\hline 601 & Grocery, retail & 243 & Sales, supervisors & 1 & 0 & 0 & 1 \\
\hline $\begin{array}{l}601 \\
601\end{array}$ & $\begin{array}{l}\text { Grocery, retail } \\
\text { Grocery, retail }\end{array}$ & $\begin{array}{l}274 \\
276\end{array}$ & $\begin{array}{l}\text { Sales worker } \\
\text { Cashiers }\end{array}$ & $\begin{array}{l}0 \\
0\end{array}$ & $\begin{array}{l}0 \\
0\end{array}$ & $\begin{array}{l}0 \\
0\end{array}$ & 1 \\
\hline 601 & Grocery, retail & 686 & Butchers, meat cutters & 1 & 0 & 0 & 1 \\
\hline 601 & Grocery, retail & 687 & Bakers & 1 & 1 & 0 & 1 \\
\hline 601 & Grocery, retail & 786 & $\begin{array}{l}\text { Handcutters, trimming } \\
\text { occupations }\end{array}$ & 1 & 1 & 0 & 1 \\
\hline 601 & Grocery, retail & 877 & Stock handlers, baggers & 1 & 0 & 0 & 1 \\
\hline 602 & $\begin{array}{l}\text { Dairy products, store, } \\
\text { retail }\end{array}$ & 243 & Supervisors and proprietors & 1 & 0 & 0 & 1 \\
\hline 610 & Retail bakery & & $\ldots \ldots$ & 1 & 1 & 1 & 1 \\
\hline 610 & Retail bakery & 687 & Bakers & 1 & 0 & 0 & 1 \\
\hline 611 & Food store, NEC & 243 & Supervisors and proprietors & 0 & 0 & 0 & 1 \\
\hline 621 & Gas service station & 885 & $\begin{array}{l}\text { Garage and service station } \\
\text { occupations }\end{array}$ & 1 & 0 & 0 & 0 \\
\hline 641 & Eating and drinking places & & $\ldots \ldots$ & 1 & 1 & 1 & 1 \\
\hline 641 & Eating and drinking places & 019 & Managers & 0 & 0 & 0 & 1 \\
\hline 641 & Eating and drinking places & 276 & Cashiers & 0 & 0 & 0 & 1 \\
\hline 641 & Eating and drinking places & 433 & $\begin{array}{l}\text { Food and service occupations, } \\
\text { supervisors }\end{array}$ & 1 & 1 & 0 & 1 \\
\hline 641 & Eating and drinking places & 435 & Waiters and waitresses & 0 & 0 & 0 & 1 \\
\hline 641 & Eating and drinking places & 436 & Cooks & 1 & 0 & 0 & 1 \\
\hline 641 & Eating and drinking places & 443 & Waiters and waitress assistants & 0 & 0 & 0 & 1 \\
\hline 641 & Eating and drinking places & 889 & Laborers & 1 & 1 & 0 & 1 \\
\hline 712 & $\begin{array}{l}\text { Real estate and real } \\
\text { estate insurance }\end{array}$ & 453 & Janitors & 1 & 1 & 0 & 1 \\
\hline 712 & $\begin{array}{l}\text { Real estate and real } \\
\text { estate insurance }\end{array}$ & 486 & Groundskeepers and gardeners & 1 & 1 & 1 & 1 \\
\hline 722 & Services to dwellings & 453 & Janitors & 1 & 1 & 0 & 1 \\
\hline 802 & $\begin{array}{l}\text { Miscellaneous entertainment } \\
\text { services }\end{array}$ & 453 & Janitors & 1 & 1 & 0 & 1 \\
\hline 831 & Hospitals & & $\ldots$ & 1 & 1 & 1 & 1 \\
\hline 831 & Hospitais & 059 & Engineers & 0 & 0 & 0 & 1 \\
\hline 831 & Hospitals & 098 & Inhalation therapists & 1 & 1 & 0 & 1 \\
\hline 831 & Hospitais & 444 & Miscellaneous food preparers & 1 & 0 & 0 & 1 \\
\hline 831 & Hospitals & 446 & Health aides & 1 & 0 & 0 & 1 \\
\hline 831 & Hospitals & 447 & Nurses aides, orderlies & 1 & 0 & 0 & 1 \\
\hline 831 & Hospitals & 448 & Cleaning supervisors & 1 & 1 & 0 & 1 \\
\hline 831 & Hospitals & 748 & Dry cleaning machine operator & 1 & 0 & 0 & 1 \\
\hline 832 & $\begin{array}{l}\text { Nursing and personal care } \\
\text { facilities }\end{array}$ & 019 & Managers & 1 & 0 & 0 & 1 \\
\hline 832 & $\begin{array}{l}\text { Nursing and personal care } \\
\text { facilities }\end{array}$ & 446 & Health aids & 1 & 0 & 0 & 1 \\
\hline 832 & $\begin{array}{l}\text { Nursing and personal care } \\
\text { facilities }\end{array}$ & 453 & Janitors & 1 & 1 & 1 & 1 \\
\hline 832 & $\begin{array}{l}\text { Nursing and personal care } \\
\text { facilities }\end{array}$ & 549 & Nonspecified mechanics & 0 & 1 & 0 & 1 \\
\hline 842 & $\begin{array}{l}\text { Elementary and secondary } \\
\text { schools }\end{array}$ & 453 & Janitors & 1 & 1 & 1 & 1 \\
\hline 850 & Colleges and universities & 453 & Janitors & 1 & 1 & 1 & 1 \\
\hline
\end{tabular}

a $1=$ exposure, $0=$ no exposure. 


\section{Appendix 2}

All potential maternal pesticide exposures according to the industrial hygienists' assessment

\begin{tabular}{|c|c|c|c|c|c|c|c|}
\hline \multicolumn{2}{|c|}{ Industrial code } & \multicolumn{2}{|c|}{ Occupational code } & \multirow{2}{*}{$\begin{array}{c}\begin{array}{c}\text { Disinfec- } \\
\tan ^{\mathrm{a}}\end{array} \\
0\end{array}$} & \multirow{2}{*}{$\frac{\text { Fungicide }^{a}}{1}$} & \multirow{2}{*}{$\frac{\text { Herbicide }^{a}}{1}$} & \multirow{2}{*}{$\frac{\begin{array}{c}\text { Insecti- } \\
\text { cide }^{a}\end{array}}{1}$} \\
\hline 010 & Agricultural, crops & 479 & Farm workers & & & & \\
\hline 011 & Livestock & & $\ldots$ & 1 & 1 & 1 & 1 \\
\hline 020 & Agricultural services & 487 & Animal caretakers & 1 & 0 & 0 & 1 \\
\hline 021 & Horticultural services & 486 & Groundskeepers and gardeners & 0 & 1 & 1 & 1 \\
\hline 111 & $\begin{array}{l}\text { Manufacturing, bakery } \\
\text { products }\end{array}$ & 687 & Bakers & 1 & 0 & 0 & 1 \\
\hline 160 & Pulp, papers mills & 216 & Engineering technicians & 1 & 0 & 0 & 1 \\
\hline 272 & $\begin{array}{l}\text { Manufacturing, aluminum } \\
\text { products }\end{array}$ & 709 & $\begin{array}{l}\text { Grinding and polishing } \\
\text { machine operators }\end{array}$ & 1 & 1 & 0 & 0 \\
\hline 281 & $\begin{array}{l}\text { Cutlery manufacturing } \\
\text { and hand tools }\end{array}$ & 889 & Laborers, except construction & 1 & 1 & 0 & 0 \\
\hline 290 & Screw machine production & 889 & Laborers, except construction & 1 & 1 & 0 & 0 \\
\hline 400 & Railroads & & $\ldots$ & 1 & 1 & 1 & 1 \\
\hline 550 & Wholesale groceries & 243 & $\begin{array}{l}\text { Sales supervisors and } \\
\text { proprietors }\end{array}$ & 0 & 0 & 0 & 1 \\
\hline 601 & Grocery stores & 439 & Billing clerks & 1 & 0 & 0 & 1 \\
\hline 601 & Grocery stores & 888 & Hand packers and packagers & 0 & 0 & 1 & 1 \\
\hline 602 & Dairy stores & 243 & $\begin{array}{l}\text { Sales supervisors and } \\
\text { proprietors }\end{array}$ & 1 & 0 & 0 & 1 \\
\hline 610 & Retail bakery & 687 & Bakers & 1 & 0 & 0 & 1 \\
\hline 611 & Food services, NEC & 274 & Sales workers & 0 & 0 & 0 & 1 \\
\hline 641 & Eating and drinking places & 019 & Managers & 0 & 0 & 0 & 1 \\
\hline 641 & Eating and drinking places & 276 & Cashiers & 0 & 0 & 0 & 1 \\
\hline 641 & Eating and drinking places & 337 & Bookkeepers, accounting & 0 & 0 & 0 & 1 \\
\hline 641 & Eating and drinking places & 444 & Food preparer & 1 & 0 & 0 & 1 \\
\hline 722 & Services to dwellings & 453 & Janitors & 1 & 1 & 0 & 1 \\
\hline 831 & Hospitals & & $\ldots \ldots$ & 1 & 1 & 1 & 1 \\
\hline 831 & Hospitals & 015 & Managers, medicine and health & 0 & 0 & 0 & 1 \\
\hline 831 & Hospitals & 023 & Accountant managers & 0 & 0 & 0 & 1 \\
\hline 831 & Hospitals & 037 & $\begin{array}{l}\text { Management related } \\
\text { occupations }\end{array}$ & 0 & 0 & 0 & 1 \\
\hline 831 & Hospitals & 084 & Physicians & 1 & 0 & 0 & 1 \\
\hline 831 & Hospitals & 096 & Pharmacists & 1 & 0 & 0 & 1 \\
\hline 831 & Hospitals & 097 & Dieticians & 0 & 0 & 0 & 1 \\
\hline 831 & Hospitals & 098 & Inhalation therapists & 1 & 1 & 0 & 1 \\
\hline 831 & Hospitals & 159 & Teachers & 0 & 0 & 0 & 1 \\
\hline 831 & Hospitals & 207 & Licensed practical nurses & 1 & 0 & 0 & 1 \\
\hline 831 & Hospitals & 274 & Sales workers & 0 & 0 & 0 & 1 \\
\hline 831 & Hospitals & 313 & Secretaries & 0 & 0 & 0 & 1 \\
\hline 831 & Hospitals & 344 & $\begin{array}{l}\text { Billing, calculation machine } \\
\text { operators }\end{array}$ & 0 & 0 & 0 & 1 \\
\hline 831 & Hospitals & 375 & Insurance adjusters & 0 & 0 & 0 & 1 \\
\hline 831 & Hospitals & 379 & Office clerks & 0 & 0 & 0 & 1 \\
\hline 831 & Hospitals & 444 & Food preparers & 1 & 0 & 0 & 1 \\
\hline 831 & Hospitals & 446 & Health aids & 1 & 0 & 0 & 1 \\
\hline 832 & $\begin{array}{l}\text { Nursing and personal care } \\
\text { facilities }\end{array}$ & & $\ldots$ & 1 & 1 & 1 & 1 \\
\hline 832 & $\begin{array}{l}\text { Nursing and personal care } \\
\text { facilities }\end{array}$ & 015 & Health managers & 0 & 0 & 0 & 1 \\
\hline 832 & $\begin{array}{l}\text { Nursing and personal care } \\
\text { facilities }\end{array}$ & 019 & Managers & 1 & 0 & 0 & 1 \\
\hline 832 & $\begin{array}{l}\text { Nursing and personal care } \\
\text { facilities }\end{array}$ & 095 & Registered nurses & 1 & 0 & 0 & 1 \\
\hline 832 & $\begin{array}{l}\text { Nursing and personal care } \\
\text { facilities }\end{array}$ & 097 & Dieticians & 1 & 0 & 0 & 1 \\
\hline
\end{tabular}


Appendix 2. Continued.

\begin{tabular}{|c|c|c|c|c|c|c|c|}
\hline \multicolumn{2}{|c|}{ Industrial code } & \multicolumn{2}{|c|}{ Occupational code } & \multirow{2}{*}{$\frac{\begin{array}{c}\text { Disinfec- } \\
\tan ^{\mathrm{a}}\end{array}}{1}$} & \multirow{2}{*}{$\frac{\text { Fungicide }^{\mathrm{a}}}{0}$} & \multirow{2}{*}{$\frac{\text { Herbicide }^{\mathrm{a}}}{0}$} & \multirow{2}{*}{$\frac{\begin{array}{c}\text { Insecti- } \\
\text { cide }^{a}\end{array}}{1}$} \\
\hline 832 & $\begin{array}{l}\text { Nursing and personal care } \\
\text { facilities }\end{array}$ & 207 & Licensed practical nurses & & & & \\
\hline 832 & $\begin{array}{l}\text { Nursing and personal care } \\
\text { facilities }\end{array}$ & 319 & Receptionists & 0 & 0 & 0 & 1 \\
\hline 832 & $\begin{array}{l}\text { Nursing and personal care } \\
\text { facilities }\end{array}$ & 389 & $\begin{array}{l}\text { Administrative support } \\
\text { occupations }\end{array}$ & 0 & 0 & 0 & 1 \\
\hline 832 & $\begin{array}{l}\text { Nursing and personal care } \\
\text { facilities }\end{array}$ & 445 & Dental assistants & 1 & 0 & 0 & 1 \\
\hline 832 & $\begin{array}{l}\text { Nursing and personal care } \\
\text { facilities }\end{array}$ & 446 & Health aides & 1 & 0 & 0 & 1 \\
\hline 862 & Child care services & 468 & Child care workers & 0 & 0 & 0 & 1 \\
\hline
\end{tabular}

a $1=$ exposure, $0=$ no exposure.

Received for publication: 25 June 1993 